\title{
PROYEKSI KETAHANAN PANGAN PROVINSI NUSA TENGGARA TIMUR TAHUN 2015-2045 DITINJAU DARI KETERSEDIAAN, KEBUTUHAN, DAN PERSEDIAAN BERAS
}

\author{
Alvin Anindita Katon Sumunar, Satrio Budiman* \\ Program Studi Geografi Lingkungan, Fakultas Geografi, Universitas Gadjah Mada \\ Jl. Kaliurang km. 4, Senolowo, Sinduadi, Mlati, Sleman, Yogyakarta 55281 \\ *Corresponding author: satriobudiman28@mail.ugm.ac.id
}

\begin{abstract}
Regional independence in fulfilling food demand is expected to increase agriculture products, both in the diversification aspect and food management. This paper aims to determine how food development strategies are, especially rice, in this climate change situation nowadays. Food planning in East Nusa Tenggara Province is done by rice availability, demand, and supply in 2015-2045. According to scenarios, these projections describe that rice supply in East Nusa Tenggara Province is surplus while the harvest area is increasing and deficit while the harvest area is decreasing. Therefore, food planning is needed regarding food availability to remain food supply in the latter days. Food demand planning can be used as a policy basis to make food supply still stable, increase the welfare of farmers and society, and even increase both East Nusa Tenggara Province's GDRP and Indonesia's GDP.
\end{abstract}

Keywords: rice, planning, projection, policy

\begin{abstract}
Abstrak: Kemandirian daerah dalam memenuhi kebutuhan pangan diharapkan mampu menambah kesanggupan produksi pertanian, baik dalam aspek manajemen, maupun diversifikasi pangan. Tulisan ini bertujuan mengetahui dan merencanakan strategi pembangunan pangan yang tepat dalam ketahanan pangan lokal, terutama beras pada kondisi perubahan iklim yang terjadi saat ini. Perencanaan pangan di Provinsi NTT dilakukan dengan proyeksi ketersediaan, kebutuhan, dan persediaan beras tahun 2015-2045. Proyeksi yang dilakukan sesuai skenario menggambarkan persediaan beras di Provinsi NTT mengalami surplus saat terjadi kenaikan luas panen dan defisit saat terjadi penurunan luas panen. Oleh karena itu, perlu dilakukan perencanaan yang berkaitan dengan kebutuhan pangan agar persediaan pangan di kemudian hari masih tetap terjaga. Perencanaan kebutuhan pangan dapat dijadikan sebagai dasar suatu kebijakan yang bertujuan agar persediaan pangan tetap stabil, meningkatkan kesejahteraan petani dan masyarakat, dan bahkan meningkatkan PDRB Provinsi NTT maupun PDB Indonesia.
\end{abstract}

Kata kunci: beras, perencanaan, proyeksi, kebijakan

\section{PENDAHULUAN}

Sektor pertanian adalah sektor utama yang memiliki peran penting dalam penyerapan tenaga kerja, peningkatan sektor ekonomi, dan penyumbang devisa negara sehingga memiliki kontribusi yang besar kepada perekonomian nasional (Badan Pusat Statistik Provinsi NTT, 2019a). Selain itu, sektor pertanian dapat menjadi penggerak bagi beberapa sektor lainnya yang berpengaruh pada perekonomian nasional. Melalui kondisi tersebut, muncul perhatian berkaitan dengan data-data mengenai sektor pertanian yang lengkap dan akurat untuk menjadi referensi bagi pemerintah yang digunakan dalam formulasi kebijakan. Oleh karena itu, hubungan antara kesejahteraan petani dan pembangunan nasional dengan 
sektor pertanian saling bersimbiosis satu sama lain (Nirzalin dan Maliati, 2017). Salah satu terobosan yang dilakukan pemerintah dalam membangun sektor pertanian adalah dengan revolusi hijau. Namun, revolusi hijau dinilai gagal karena dalam penyelenggaraannya terlalu berporos pada pemerintah. Revolusi hijau juga menyebabkan kerusakan lingkungan karena penggunaan pupuk, pestisida, teknologi berat, dan irigasi yang dilakukan dalam jumlah besar. Selain itu, kegagalan tersebut juga terlihat dari tingkat kesejahteraan penduduk yang tidak dinamis (Mardiyaningsih dan Dharmawan, 2010).

Menurut UU No. 18 Tahun 2012, pangan adalah komoditas utama yang termasuk sebagai kebutuhan dasar manusia yang paling utama dan pemenuhan pangan tersebut adalah bagian dari hak asasi manusia. Ketahanan pangan adalah keadaan di mana masing-masing penduduk dan negara memiliki kebutuhan pangan yang terpenuhi, baik dalam hal jumlah, maupun kualitas dan distribusinya (UndangUndang No. 18 Tahun 2012 Tentang Pangan, 2012). Di situlah terdapat pentingnya kemandirian daerah dalam menyanggupi kebutuhan pangan dengan cara meningkatkan produktivitas pertanian, baik dalam manajemen, maupun diversifikasi pangan (Widodo et al., 2013). Beras digunakan sebagai acuan dari perencanaan panngan karena beras adalah komoditas makanan pokok di Indonesia. Beras juga dijadikan sebagai referensi dalam menilai kondisi sosial politik dan kesejahteraan masyarakat. Besarnya konsumsi beras disebabkan karena perubahan pola konsumsi dari pangan lokal menjadi beras sebagai makanan pokok (Teda et al., 2020).

Namun, baru-baru ini ketersediaan pangan nasional masih belum mampu mengakomodasi seluruh kebutuhan pangan penduduknya, khususnya di daerah atau provinsi masing-masing. Permasalahan ketahanan pangan merupakan masalah negara yang menjadi isu strategis karena alih fungsi lahan (Pratama et al., 2019). Hal ini terjadi karena belum adanya keefektifan dalam penyusunan dan sinkronisasi antarlembaga negara, seperti instansi pertanian, perumahan, dan perdagangan. Perubahan iklim yang cukup signifikan juga menjadi salah satu penyebab permasalahan ketahanan pangan. Selain itu, pola kehidupan masyarakat juga akan berubah karena adanya pemutusan regenerasi petani yang terjadi pada generasi muda.

Berkaca pada permasalahan di atas, tujuan dilakukannya penelitian ini adalah untuk mengetahui dan merencanakan strategi pembangunan pangan yang tepat dalam ketahanan pangan lokal di Provinsi Nusa Tenggara Timur (NTT) pada kondisi perubahan iklim saat ini. Provinsi NTT memiliki luas wilayah daratan sebesar 47.931,54 $\mathrm{km}^{2}$. Provinsi NTT dibagi menjadi 21 kabupaten dan 1 kota sebagai ibukotanya, yaitu Kota Kupang. Secara umum, Provinsi NTT tergolong panas dengan suhu rata-rata sebesar $27-32^{\circ} \mathrm{C}$ (Badan Pusat Statistik Provinsi NTT, 2020). Berikut ini adalah wilayah kajian yang akan diteliti pada tulisan ini.

Perencanaan tersebut dapat diusut dengan mengubah kerangka berpikir generasi muda yang konsumtif menjadi produktif melalui pengetahuan di bidang pertanian, menanami lahan kosong dengan tanaman pangan sehingga efektivitas lahan menjadi naik, dan menyosialisasikan kekuatan pangan lokal di Provinsi NTT. Hal tersebut dapat mengurangi ketergantungan pangan pada provinsi lain dan mampu mewujudkan ketahanan pangan. Ketersediaan pangan dapat terpenuhi jika diawali dari tercukupinya pangan pada tingkat keluarga. Hal tersebut juga dapat dilihat dari kecukupan gizi pada setiap individu sehingga status gizi masyarakat Provinsi NTT juga akan terpenuhi.

Oleh karena itu, perlu dilakukan perencanaan yang berkaitan dengan kebutuhan pangan agar ketersediaan pangan di kemudian hari masih tetap terjaga. Perencanaan berperan penting dalam memutuskan arah ke mana berjalannya suatu program. Perencanaan juga menjadi salah satu aspek penting yang berkontribusi dalam kesuksesan suatu program. Perkiraan struktur penduduk, seperti jumlah penduduk, usia penduduk, dan jenis kelamin merupakan hal penting ketika akan menyusun suatu perencanaan kebijakan dan program pembangunan di suatu wilayah (Dinas Kependudukan dan Pencatatan Sipil Kota Bontang, 2013). Penduduk adalah salah satu aspek penting sebagai kunci, sumber daya, dan aset jangka panjang dalam analisis ekonomi pembangunan (Heryanah, 2015). Hal ini juga 


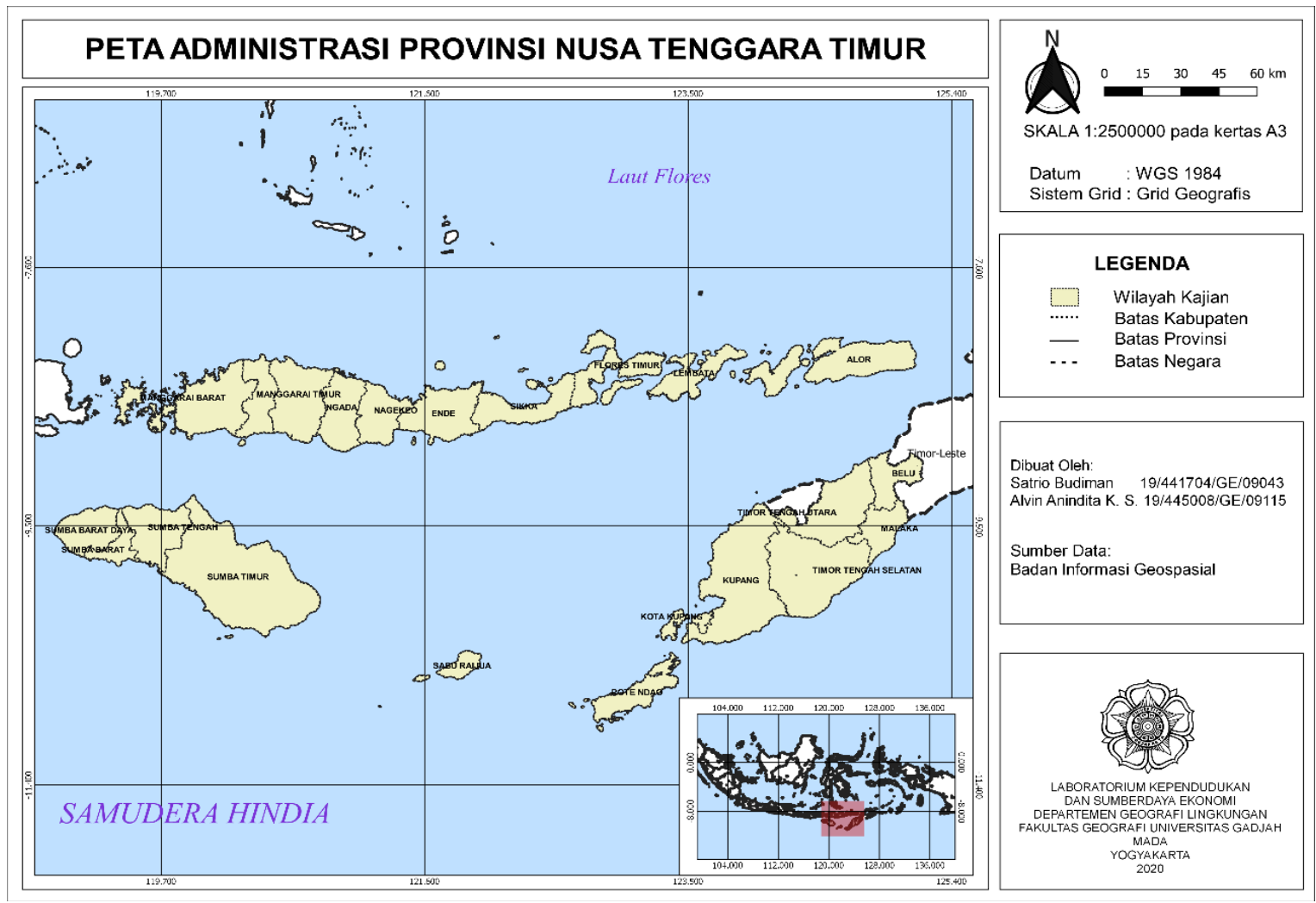

Gambar 1. Peta administrasi Provinsi NTT

berhubungan dengan salah satu kebijakan pemerintah dalam Rencana Pembangunan Jangka Menengah Nasional (RPJMN) 20202024, yaitu terlindunginya ketahanan pangan nasional yang akan dikembangkan berdasarkan pada keragaman sumber daya pangan dan manusia sehingga dapat menyediakan pangan dan nutrisi yang terpenuhi dalam kualitas dan jumlah, serta harga yang ramah (Kementerian Pertanian RI, 2020). Melalui hal tersebut, diharapkan seluruh elemen masyarakat dapat menjangkau dan mendapatkan asupan yang berkualitas, bergizi, dan aman untuk dikonsumsi sehingga ketahanan pangan yang ada di Provinsi NTT tetap kokoh. Selain itu, Provinsi NTT memiliki potensi sumber daya yang memadai sehingga pembangunan di Provinsi NTT masih dapat terus ditingkatkan terutama untuk pembangunan pertanian tanaman pangan.

\section{METODE PENELITIAN}

Penelitian ini menerapkan metode deskriptif kuantitatif. Metode ini menggunakan angkaangka, pengolahan statistika, dan percobaan terkontrol untuk memaksimalkan objektivitas desain (Hamdi dan Bahruddin, 2015). Pendekatan kuantitatif akan menghasilkan hasil penelitian yang tidak menyimpang dari kondisi sebenarnya karena instrumen dan analisis statistik yang digunakan valid dan tepat (Yusuf, 2017), sedangkan metode deskriptif akan menghasilkan deskripsi dan lukisan secara sistematis yang aktual mengenai fenomena yang diselidiki (Rukajat, 2018).

Penelitian ini menggunakan teknik pengumpulan data sekunder. Data sekunder yang digunakan adalah data sensus penduduk Provinsi NTT tahun 2010 dan proyeksi penduduk tahun 2011-2015, serta luas panen dan produktivitas lahan tahun 2009-2015. Data sekunder yang digunakan tersebut dipublikasikan di laman resmi Badan Pusat Statistik (BPS). Data sekunder tersebut nantinya akan digunakan sebagai dasar untuk menggambarkan dan merencanakan ketersediaan, kebutuhan, dan persediaan beras di Provinsi NTT pada masa mendatang.

Proyeksi ketersediaan beras dilakukan dengan menggunakan rata-rata luas panen dan produktivitas yang nantinya laju pertumbuhannya dilakukan sesuai skenario. Kebutuhan beras tahun 2010-2015 dilakukan 
dengan pendekatan kebutuhan fisik minimum (KFM). KFM adalah kebutuhan minimum yang dibutuhkan seorang pekerja terhadap pangan, sandang, papan, pendidikan, dan kesehatan agar dapat hidup dan bekerja dengan layak (International Labour Organization, 2013). KFM didasarkan pada kebutuhan kalori setiap orang per hari sebesar 2600 kalori atau setara dengan 265 kilogram beras per orang per tahun (Moniaga, 2011). KFM dapat diketahui dengan rumus perhitungan sebagai berikut.

KFM = Jumlah penduduk $\times 265 \mathrm{~kg} / \mathrm{tahun}$

Jumlah penduduk yang digunakan adalah jumlah penduduk menurut sensus penduduk tahun 2010 dan proyeksi penduduk tahun 2011-2015 yang dipublikasikan oleh BPS. KFM tersebut digunakan untuk menghitung proyeksi kebutuhan beras tahun 2016-2045 melalui metode kuadrat terkecil. (Least Square Method/LSQ). Analisis tren tersebut dapat dituliskan pada persamaan di bawah ini. $y^{\prime}=a+b x$

$a=\frac{\sum \mathrm{y}}{\mathrm{n}}$

$b=\frac{\sum x y}{\sum\left(x^{2}\right)}$

$y=$ variabel nilai tren yang diketahui

$y^{\prime}=$ variabel nilai tren yang dicari

$x=$ variabel waktu (tahun)

$a=$ konstanta nilai tren pada tahun dasar

$b=$ rata-rata pertumbuhan nilai tren setiap tahun

Melalui data proyeksi ketersediaan dan kebutuhan beras tahun 2015-2045, maka dapat diketahui persediaan beras di Provinsi NTT tahun 2015-2045 yang dapat dihitung melalui perhitungan sebagai berikut.

Persediaan beras $($ ton $)=$ Ketersediaan beras Kebutuhan beras

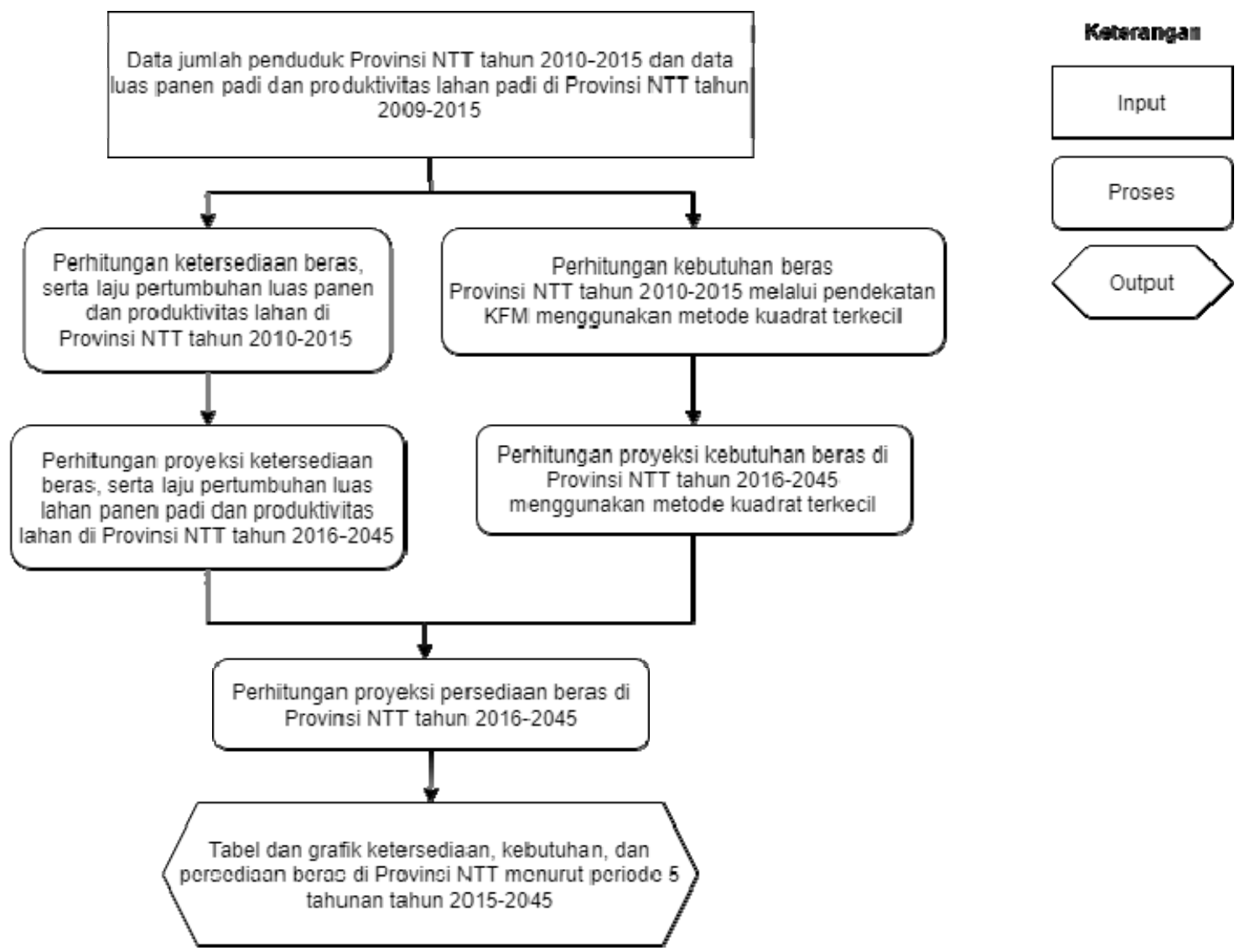

Gambar 2. Diagram alir penelitian 
HASIL DAN PEMBAHASAN

Proyeksi Ketersediaan, Kebutuhan, dan Persediaan Beras di Provinsi NTT

Sektor pertanian di Provinsi NTT berkontribusi besar terhadap PDRB sehingga menjadi salah satu sektor unggulan. Sektor pertanian menjadi tempat di mana sebagian besar masyarakat Provinsi NTT menyandarkan hidupnya. Selain itu, sektor pertanian juga memiliki peran penting karena dapat menyediakan pangan bagi masyarakat dan industri di Provinsi NTT sehingga diharapkan mampu dan layak dijadikan sebagai komoditas yang dapat diekspor ke wilayah lainnya. Namun, tugas utama sektor pertanian adalah menyediakan pangan bagi seluruh penduduk di wilayah tersebut di masa yang akan datang. Tugas tersebut tidaklah mudah karena laju pertumbuhan penduduk yang meningkat menyebabkan permintaan produk-produk pertanian juga akan meningkat di tengahtengah banyaknya hambatan yang harus dihadapi pada pembangunan pertanian.

Penelitian ini dilakukan dengan memproyeksikan ketersediaan, kebutuhan, dan persediaan beras di Provinsi Nusa Tenggara
Timur tahun 2015-2045. Perhitungan proyeksi ketersediaan beras di Provinsi NTT dilakukan dengan perhitungan pada data dasar tahun 2010-2015. Data-data tersebut adalah luas panen, produktivitas lahan, masa panen, dan produksi beras bersih. Masa panen yang digunakan di dalam perhitungan adalah 3 kali masa panen karena masa tersebut merupakan masa panen padi yang umum terjadi di Indonesia. Produktivitas lahan dihitung dengan perhitungan laju pertumbuhan geometri menggunakan data dasar produktivitas lahan tahun 2010-2015. Luas panen dihitung dengan dua skenario, yaitu:

1. Skenario 1: Luas panen dihitung menggunakan perhitungan laju pertumbuhan geometri sehingga menghasilkan laju pertumbuhan luas panen yang konstan.

2. Skenario 2: Luas panen diasumsikan terus mengalami penurunan $1,5 \%$ setiap tahunnya.

Perhitungan laju pertumbuhan luas panen dan produktivitas dilakukan dengan menggunakan

Tabel 1. Hasil perhitungan proyeksi ketersediaan beras di Provinsi NTT menurut skenario 1 tahun 20162045

\begin{tabular}{rrrrrrrc}
\hline Tahun & $\begin{array}{c}\text { Luas } \\
\text { Panen (ha) }\end{array}$ & $\begin{array}{c}\text { Produktivitas } \\
\text { (ku/ha) }\end{array}$ & Konversi & $\begin{array}{c}\text { Masa } \\
\text { Panen }\end{array}$ & $\begin{array}{c}\text { Ketersediaan } \\
\text { Beras (ton) }\end{array}$ & $\begin{array}{c}\text { Laju } \\
\text { Pertumbuhan } \\
\text { Luas Panen }\end{array}$ & $\begin{array}{c}\text { Laju } \\
\text { Pertumbuhan } \\
\text { Produktivitas }\end{array}$ \\
\hline 2009 & 194219 & 31,27 & 0,58511 & 3 & 1066058 & - & - \\
2010 & 174674 & 31,8 & 0,58511 & 3 & 975027 & $-0,1006$ & 0,0169 \\
2011 & 195201 & 30,3 & 0,58511 & 3 & 1038212 & 0,1175 & $-0,0472$ \\
2012 & 200094 & 34,91 & 0,58511 & 3 & 1226154 & 0,0251 & 0,1521 \\
2013 & 222469 & 32,8 & 0,58511 & 3 & 1280868 & 0,1118 & $-0,0604$ \\
2014 & 246750 & 44,1 & 0,58511 & 3 & 1910104 & 0,1091 & 0,3445 \\
2015 & 266242 & 31,55 & 0,58511 & 3 & 1474474 & 0,079 & $-0,2846$ \\
2016 & 281414 & 32,19 & 0,58511 & 3 & 1590034 & 0,057 & 0,0202 \\
2017 & 297450 & 32,84 & 0,58511 & 3 & 1714651 & 0,057 & 0,0202 \\
2018 & 314400 & 33,5 & 0,58511 & 3 & 1849035 & 0,057 & 0,0202 \\
2019 & 332316 & 34,18 & 0,58511 & 3 & 1993951 & 0,057 & 0,0202 \\
2020 & 351253 & 34,87 & 0,58511 & 3 & 2150225 & 0,057 & 0,0202 \\
2025 & 463409 & 38,55 & 0,58511 & 3 & 3135673 & 0,057 & 0,0202 \\
2030 & 611376 & 42,61 & 0,58511 & 3 & 4572751 & 0,057 & 0,0202 \\
2035 & 806589 & 47,1 & 0,58511 & 3 & 6668442 & 0,057 & 0,0202 \\
2040 & 1064133 & 52,06 & 0,58511 & 3 & 9724588 & 0,057 & 0,0202 \\
2045 & 1403912 & 57,55 & 0,58511 & 3 & 14181364 & 0,057 & 0,0202 \\
\hline
\end{tabular}

Sumber: Provinsi NTT dalam Angka, 2009-2015 (Diolah) 
Sumunar, A. A. K., Budiman, S. : Proyeksi Ketahanan Pangan Provinsi ...

Tabel 2. Hasil perhitungan proyeksi ketersediaan beras di Provinsi NTT menurut skenario 2 tahun 20162045

\begin{tabular}{cccccccc}
\hline Tahun & $\begin{array}{c}\text { Luas } \\
\text { Panen (ha) }\end{array}$ & $\begin{array}{c}\text { Produktivitas } \\
\text { (ku/ha) }\end{array}$ & Konversi & $\begin{array}{c}\text { Masa } \\
\text { Panen }\end{array}$ & $\begin{array}{c}\text { Ketersediaan } \\
\text { Beras (ton) }\end{array}$ & $\begin{array}{c}\text { Laju } \\
\text { Pertumbuhan } \\
\text { Luas Panen }\end{array}$ & $\begin{array}{c}\text { Laju } \\
\text { Pertumbuhan } \\
\text { Produktivitas }\end{array}$ \\
\hline 2009 & 194219 & 31,27 & 0,58511 & 3 & 1066058 & - & - \\
2010 & 174674 & 31,8 & 0,58511 & 3 & 975027 & $-0,1006$ & 0,0169 \\
2011 & 195201 & 30,3 & 0,58511 & 3 & 1038212 & 0,1175 & $-0,0472$ \\
2012 & 200094 & 34,91 & 0,58511 & 3 & 1226154 & 0,0251 & 0,1521 \\
2013 & 222469 & 32,8 & 0,58511 & 3 & 1280868 & 0,1118 & $-0,0604$ \\
2014 & 246750 & 44,1 & 0,58511 & 3 & 1910104 & 0,1091 & 0,3445 \\
2015 & 266242 & 31,55 & 0,58511 & 3 & 1474474 & 0,079 & $-0,2846$ \\
2016 & 262248 & 32,19 & 0,58511 & 3 & 1481747 & $-0,015$ & 0,0202 \\
2017 & 258315 & 32,84 & 0,58511 & 3 & 1489055 & $-0,015$ & 0,0202 \\
2018 & 254440 & 33,5 & 0,58511 & 3 & 1496399 & $-0,015$ & 0,0202 \\
2019 & 250623 & 34,18 & 0,58511 & 3 & 1503780 & $-0,015$ & 0,0202 \\
2020 & 246864 & 34,87 & 0,58511 & 3 & 1511197 & $-0,015$ & 0,0202 \\
2025 & 228896 & 38,55 & 0,58511 & 3 & 1548835 & $-0,015$ & 0,0202 \\
2030 & 212236 & 42,61 & 0,58511 & 3 & 1587411 & $-0,015$ & 0,0202 \\
2035 & 196789 & 47,1 & 0,58511 & 3 & 1626947 & $-0,015$ & 0,0202 \\
2040 & 182466 & 52,06 & 0,58511 & 3 & 1667468 & $-0,015$ & 0,0202 \\
2045 & 169186 & 57,55 & 0,58511 & 3 & 1708998 & $-0,015$ & 0,0202 \\
\hline
\end{tabular}

Sumber: Provinsi NTT dalam Angka, 2009-2015 (Diolah)

Tabel 3. Perhitungan proyeksi kebutuhan beras di Provinsi NTT tahun 2010-2015

\begin{tabular}{ccccc}
\hline Tahun & $\begin{array}{c}\text { Kebutuhan Beras (kg/tahun) } \\
(\mathrm{y})\end{array}$ & $\mathrm{x}$ & $\mathrm{xy}$ & $\mathrm{x}^{2}$ \\
\hline 2010 & 1247140880 & -3 & -3741422640 & 9 \\
2011 & 1250433770 & -2 & -2500867540 & 4 \\
2012 & 1290875155 & -1 & -1290875155 & 1 \\
2013 & 1312801255 & 1 & 1312801255 & 1 \\
2014 & 1334777705 & 2 & 2669555410 & 4 \\
2015 & 1356816165 & 3 & 4070448495 & 9 \\
Total & 7792844930 & 0 & 519639825 & 28 \\
\hline
\end{tabular}

Sumber: Provinsi NTT dalam Angka, 2010-2015 (Diolah)

data tahun tersebut dengan data tahun sebelumnya. Sebagai contoh, untuk menghitung laju pertumbuhan luas panen tahun 2010, maka digunakan data luas panen tahun 2009 dan 2010 yang dihitung menggunakan rumus laju pertumbuhan geometri. Tabel 1 menampilkan hasil perhitungan proyeksi ketersediaan beras di Provinsi NTT tahun 2016-2045.

Perhitungan proyeksi kebutuhan beras di Provinsi NTT dilakukan dengan analisis tren kenaikan atau penurunan yang menerapkan Least Square Method/LSQ atau yang disebut dengan metode kuadrat terkecil. Tabel proyeksi kebutuhan beras di Provinsi NTT yang disajikan di bawah ini merupakan hasil perhitungan melalui metode tersebut. Untuk mengetahui nilai konstanta a dan b, maka dilakukan perhitungan menggunakan rumus yang sudah tertulis di atas sehingga didapatkan persamaan sebagai berikut.

$$
\begin{aligned}
y^{\prime} & =a+b x \\
& =1298807488+18558565 x
\end{aligned}
$$

Perhitungan yang telah dilakukan sebelumnya menghasilkan persamaan yang dapat digunakan 
untuk menghitung jumlah kebutuhan beras di Provinsi NTT dalam periode tahun 2016-2045 dengan menggunakan data dasar tahun 20102015. Perhitungan tersebut menggunakan persamaan sebagai berikut.

$y^{\prime}=1298807488+18558565 x$

Tabel 4 menampilkan hasil perhitungan kebutuhan beras di Provinsi NTT tahun 20162045. Sementara itu, perhitungan persediaan beras adalah dengan mengurangkan ketersediaan beras dengan kebutuhan beras. Hasil perhitungan proyeksi persediaan beras (dengan pembulatan) di Provinsi NTT tahun 2015-2045 ditampilkan dalam Tabel 5.
Perhitungan skenario 1 yang menghasilkan tabel dan grafik terlihat memiliki kestabilan dalam hal ketersediaan, kebutuhan, dan persediaan untuk memenuhi setiap kebutuhan. Melalui skenario 1 ini, luas panen dihitung dengan laju pertumbuhan geometri sehingga hasilnya terlihat konstan dan stabil. Ketersediaan beras setiap tahunnya selalu mengalami kenaikan yang signifikan.

Ketersediaan beras pada di Provinsi NTT pada tahun 2020 diproyeksikan sebanyak 2.150.225 ton dan akan terus meningkat sampai tahun 2045, yaitu sebanyak 14.181.364 ton. Sementara itu, kenaikan kebutuhan beras tidak sesignifikan kenaikan ketersediaan beras.

Tabel 4. Hasil perhitungan proyeksi kebutuhan beras di Provinsi NTT menggunakan metode kuadrat terkecil tahun 2016-2045

\begin{tabular}{ccc}
\hline Tahun & Kebutuhan Beras (kg/tahun) & Kebutuhan Beras (ton/tahun) \\
\hline 2010 & 1243131793 & 1243131,793 \\
2011 & 1261690358 & 1261690,358 \\
2012 & 1280248923 & 1280248,923 \\
2013 & 1317366054 & 1317366,054 \\
2014 & 1335924619 & 1335924,619 \\
2015 & 1354483184 & 1354483,184 \\
2016 & 1373041749 & 1373041,749 \\
2017 & 1391600314 & 1391600,314 \\
2018 & 1410158879 & 1410158,879 \\
2019 & 1428717445 & 1428717,445 \\
2020 & 1447276010 & 1447276,01 \\
2025 & 1540068836 & 1540068,836 \\
2030 & 1632861662 & 1632861,662 \\
2035 & 1725654487 & 1725654,487 \\
2040 & 1818447313 & 1818447,313 \\
2045 & 1298807488 & 1298807,488 \\
\hline
\end{tabular}

Sumber: Provinsi NTT dalam Angka, 2009-2015 (Diolah)

Tabel 5. Hasil perhitungan proyeksi persediaan beras di Provinsi NTT menurut skenario 1 tahun 2015-2045 (lima tahunan)

\begin{tabular}{cccr}
\hline Tahun & Ketersediaan Beras (ton) & Kebutuhan Beras (ton) & Persediaan Beras (ton) \\
\hline 2015 & 1474474 & 1354483 & 119991 \\
2020 & 2150225 & 1447276 & 702949 \\
2025 & 3135673 & 1540069 & 1595604 \\
2030 & 4572751 & 1632862 & 2939889 \\
2035 & 6668442 & 1725654 & 4942787 \\
2040 & 9724588 & 1818447 & 7906140 \\
2045 & 14181364 & 1911240 & 12270124 \\
\hline
\end{tabular}

Sumber: Provinsi NTT dalam Angka, 2009-2015 (Diolah) 
Sumunar, A. A. K., Budiman, S. : Proyeksi Ketahanan Pangan Provinsi ...

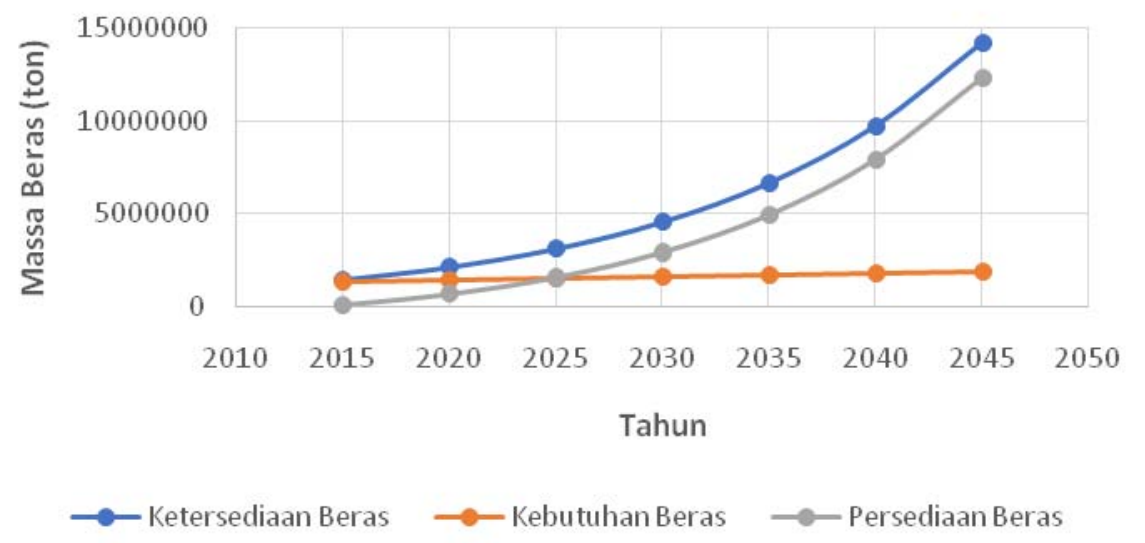

Gambar 3. Grafik proyeksi ketersediaan, kebutuhan, dan persediaan beras di Provinsi NTT menurut skenario 1 tahun 2015-2045

Tabel 6. Hasil perhitungan proyeksi persediaan beras di Provinsi NTT menurut skenario 2 tahun 2015-2045 (lima tahunan)

\begin{tabular}{cccr}
\hline Tahun & Ketersediaan Beras (ton) & Kebutuhan Beras (ton) & Persediaan Beras (ton) \\
\hline 2015 & 1474474 & 1354483 & 119991 \\
2020 & 1511197 & 1447276 & 63921 \\
2025 & 1548835 & 1540069 & 8766 \\
2030 & 1587411 & 1632862 & -45451 \\
2035 & 1626947 & 1725654 & -98708 \\
2040 & 1667468 & 1818447 & -150980 \\
2045 & 1708998 & 1911240 & -202242 \\
\hline
\end{tabular}

Sumber: Provinsi NTT dalam Angka, 2009-2015 (Diolah)

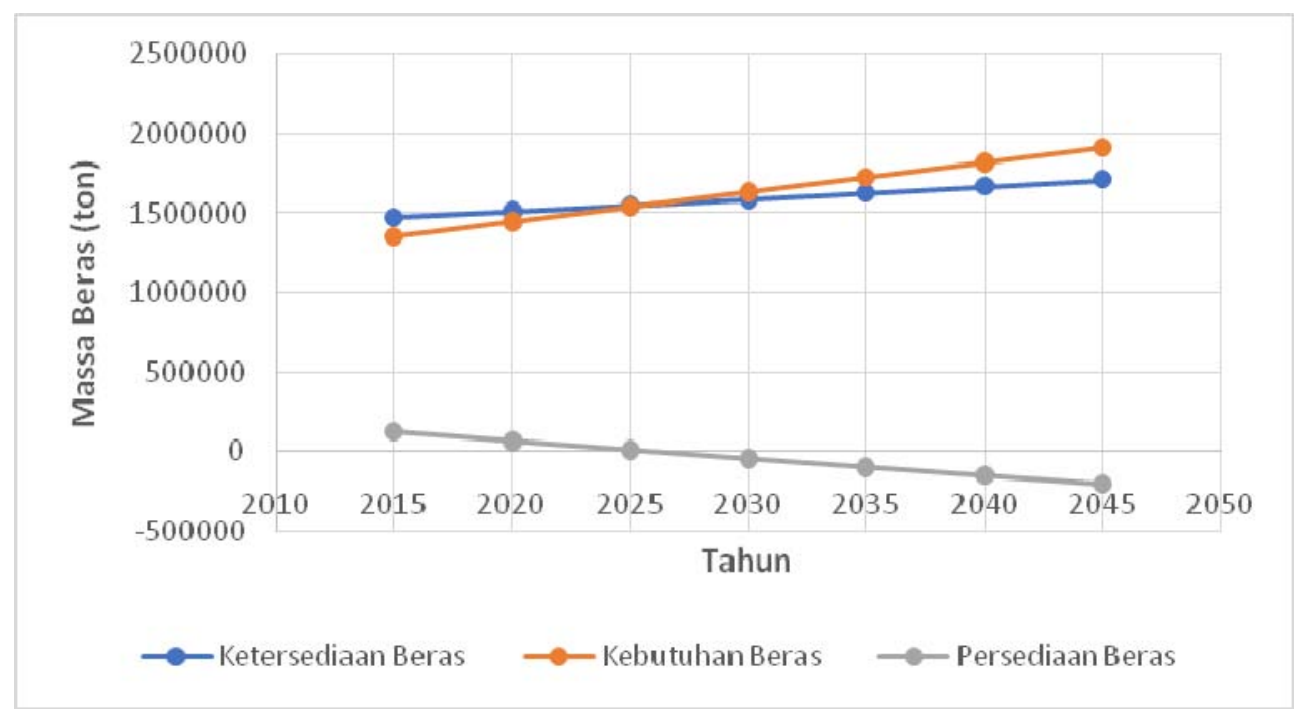

Gambar 4. Grafik proyeksi ketersediaan, kebutuhan, dan persediaan beras di Provinsi NTT menurut skenario 2 tahun 2015-2045 
Akibatnya, persediaan beras di Provinsi NTT diproyeksikan akan mengalami kenaikan secara signifikan. Persediaan beras di Provinsi NTT tahun 2020 diproyeksikan sebanyak 702.949 ton dan naik drastis pada tahun 2045 menjadi 12.270.124 ton. Tentu saja skenario 1 ini menjadi salah satu impian dari pemerintah dan juga masyarakat Provinsi Nusa Tenggara Timur karena telah diketahui bersama penduduk selalu bertambah disetiap tahunnya sehingga kebutuhan akan pangan juga pasti akan ikut bertambah dan sudah seharusnya diimbangi dengan ketersediaan dan persediaan beras yang tercukupi.

Perhitungan skenario 2 yang menghasilkan tabel dan grafik terlihat kurang stabil dibanding perhitungan skenario 1 . Skenario 2 diasumsikan bahwa luas panen berkurang $1,5 \%$ per tahunnya. Hal ini dikarenakan setiap tahun jumlah penduduk akan bertambah dan tidak bisa dipungkiri kebutuhan permukiman juga pasti akan meningkat, sedangkan hingga saat ini masih banyak perumahan yang dibangun diatas lahan pertanian. Ini jelas berdampak pada jumlah hasil panen dari lahan pertanian tersebut yang berpengaruh pada ketersediaan dan juga persediaan pangan untuk masyarakat itu sendiri. Pemerintah Provinsi NTT hingga mengancam akan menggusur perumahan yang berdiri di lahan pertanian. Hal ini terjadi di persawahan di Lembor, Manggarai Barat, Provinsi NTT yang beralih fungsi menjadi lahan perumahan padahal Lembor ini sendiri menjadi salah satu penghasil atau sentra pangan di Provinsi NTT. Apabila dilihat dari tabel lima tahunan menurut skenario 2, persediaan beras di Provinsi NTT mulai minus atau defisit pada tahun 2030 sebanyak 45.451 ton dan terus bertambah defisit hingga tahun 2045 sebanyak 202.242 ton. Hal ini tentunya sangat disayangkan karena seharusnya Provinsi Nusa Tenggara Timur bisa memiliki persediaan dan ketersediaan beras justru mengalami defisit pada persediaan beras yang menandakan masih kurang memenuhi kebutuhan dari ketersediaan beras itu sendiri.

Selain itu, penurunan luas panen di Provinsi NTT juga disebabkan oleh pengaruh cuaca/iklim, yaitu adanya fenomena El Nino. El Nino adalah gejala kondisi perairan yang menyimpang yang ditunjukkan oleh peningkatan suhu permukaan air laut di
Samudera Pasifik bagian timur dan tengah sekitar ekuator. Perubahan pola iklim ketika El Nino terjadi dapat memengaruhi organisme dan ekosistem darat dan laut (Vecchi dan Wittenberg, 2010). Salah satunya berdampak kepada lahan pertanian, terutama padi, yaitu penurunan produktivitas akibat kekeringan dan peningkatan suhu sehingga dapat menyebabkan kekeringan air. Kekeringan air tersebut menyebabkan pasokan terhadap irigasi pertanian menjadi berkurang. Selain itu, kekeringan juga dapat menyebabkan munculnya hama, seperti wereng cokelat/putih, belalang, dan jamur menjadi penyebab munculnya penyakit pada tanaman padi.

Berdasarkan hasil proyeksi perhitungan beberapa indikator ketahanan pangan tersebut, dapat dilihat bahwa ketahanan pangan Provinsi NTT saat ini dalam posisi baik. Permasalahan yang ada, yaitu lahan produktif pertanian yang mengalami konversi di Provinsi NTT menjadi salah satu penyebab masalah ketahanan pangan. Jika dilihat dari tren pembangunan yang ada di Provinsi NTT, penyusutan lahan pertanian tersebut disebabkan oleh pembangunan permukiman di daerah yang produksi pertaniannya tinggi secara pesat sehingga produktivitasnya akan makin rendah. Melalui adanya proyeksi dan evaluasi yang dilakukan terkait dengan ketahanan pangan di Provinsi NTT, diharapkan pemerintah dan pihak terkait dapat berusaha untuk menyelenggarakan riset yang bertujuan agar kualitas dan produktivitas komoditas pangan yang ada di Provinsi NTT makin baik kedepannya.

\section{Perencanaan Kebijakan Pertanian di Provinsi NTT}

Perencanaan kebutuhan pangan dapat dijadikan sebagai dasar suatu kebijakan dalam rangka penyelenggaraan ketahanan pangan. Oleh karena itu, agar pengelolaan hasil panen dan persediaan beras dapat digunakan secara bijak sesuai kebutuhan dan tepat sasaran, maka diperlukan suatu kebijakan yang bertujuan agar persediaan pangan agar tetap stabil, meningkatkan kesejahteraan petani, masyarakat, dan bahkan meningkatkan PDRB Provinsi NTT maupun PDB Indonesia. Kebijakan yang dapat diambil menurut masingmasing skenario adalah sebagai berikut. 
1. Skenario 1

Perhitungan skenario 1 menggambarkan persediaan beras di Provinsi NTT yang selalu surplus dan meningkat setiap tahunnya sehingga mencapai 12 juta ton pada tahun 2045. Hal tersebut merupakan kesempatan emas untuk Provinsi NTT di mana selain dapat memenuhi kebutuhan beras dalam provinsi, Provinsi NTT juga mampu menyediakan kebutuhan beras di provinsi lainnya sehingga dapat menjadi lumbung padi nasional di Indonesia. Bahkan, Provinsi NTT mampu mengekspor beras sampai ke mancanegara jika dilakukan dengan regulasi yang benar.

Provinsi NTT juga dapat dijadikan sebagai kawasan agropolitan di Indonesia. Kawasan agropolitan menerapkan konsep menjadikan wilayah perdesaan sebagai sistem produksi pertanian dan pengelolaan sumber daya alam (Basuki, 2012). Konsep agropolitan juga menjadi alternatif untuk mengurangi urbanisasi dan kepadatan penduduk, serta meningkatkan produktivitas pertanian (Abramson, 2019). Penerapan konsep agropolitan tersebut nantinya dapat meningkatkan kesejahteraan petani, meningkatkan keefisienan lembaga usaha tani, dan memperluas pengembangan komoditas unggulan, termasuk beras. Selain itu, dengan penerapan konsep tersebut, Provinsi NTT akan memiliki pertanian yang lebih maju dengan infrastruktur, sarana, dan prasarana yang juga maju.

2. Skenario 2

Perhitungan skenario 2 menggambarkan persediaan beras di Provinsi NTT makin menurun tiap tahunnya yang pada tahun 2045 diproyeksikan akan defisit mencapai 200 ribu ton karena terjadi penurunan luas panen setiap tahunnya. Salah satu kebijakan yang dapat diterapkan adalah dengan melakukan revitalisasi lahan pertanian pada lahan baru yang dirasa cukup luas agar dapat meningkatkan ketahanan pangan (Ichwandi, 2014). Revitalisasi dan ekstensifikasi lahan pertanian tersebut dapat dilakukan karena dari 3.829.530 hektar lahan pertanian pada tahun 2018, hanya 214.388 hektar yang berfungsi sebagai lahan sawah (Badan Pusat Statistik Provinsi NTT, 2019b). Luas lahan yang belum diusahakan merupakan kesempatan yang sangat bagus untuk mengembangkan sektor pertanian di masa mendatang sehingga dapat memenuhi ketahanan pangan.

Revitalisasi dan ekstentifikasi lahan pertanian saja tidak cukup, dalam mengolahnya juga perlu sumber daya manusia yang berkualitas. Oleh karena itu, perlu kesiapan infrastruktur secara sosial budaya agar masyarakat memiliki kultur pertanian pangan secara intensif. Peningkatan kualitas SDM tersebut juga dapat mendorong penggunaan bibit unggul. Penggunaan bibit unggul tersebut dapat meningkatkan produksi pertanian secara signifikan.

Selain itu, dalam mengelola persediaan beras agar tetap terjaga, dapat dilakukan dengan gerakan diversifikasi pangan. Permintaan beras yang terus meningkat disebabkan oleh ketergantungan masyarakat terhadap konsumsi beras sebagai makanan pokok. Peningkatan beras tersebut juga tidak lepas dari kebijakan pemerintah yang menyediakan beras dengan harga yang murah dalam jangka waktu panjang. Diversifikasi pangan tersebut merupakan salah satu solusi untuk mengurangi ketergantungan terhadap beras. Kebijakan tersebut dapat dilakukan secara bertahap. Misalnya, mengganti jagung dan ubi kayu sebagai makanan pokok dalam tiga hari selama satu minggu secara rutin.

\section{KESIMPULAN}

Melalui penelitian proyeksi yang dilakukan, Provinsi NTT akan mengalami dua kondisi berbeda sesuai dengan masing-masing skenario. Proyeksi yang dilakukan sesuai skenario 1, menggambarkan bahwa Provinsi NTT akan mengalami kenaikan ketersediaan beras yang signifikan karena kenaikan luas panen. Hal tersebut mengakibatkan persediaan beras di Provinsi NTT menjadi surplus yang tinggi mencapai 12.270.124 ton pada tahun 2045. Melalui skenario ini, Provinsi NTT diperkirakan dapat memenuhi ketahanan pangan sampai tahun 2045. Sementara itu, skenario 2 menggambarkan penurunan ketersediaan beras karena penurunan luas panen sebesar $1,5 \%$ per tahun. Hal tersebut 
mengakibatkan persediaan beras di Provinsi NTT menjadi defisit mencapai 202.242 ton.

Proyeksi berdasarkan skenario tersebut dapat dijadikan sebagai dasar perencanaan kebijakan. Skenario 1 dapat memunculkan kebijakan pengeksporan beras ke luar Provinsi NTT dan menjadikan Provinsi NTT sebagai kawasan agropolitan. Sementara itu, skenario 2 dapat memunculkan kebijakan revitalisasi dan ekstensifikasi lahan kosong, peningkatan kualitas SDM, dan diversifikasi pangan secara bertahap.

\section{DAFTAR PUSTAKA}

Abramson, D. B. (2019). Ancient and current resilience in the Chengdu Plain: Agropolitan development re-'revisited'. Urban Studies, 57(7), 1372-1397. https: //doi.org/10.1177/0042098019843020.

Badan Pusat Statistik Provinsi NTT. (2019a). Profil Sektor Pertanian Provinsi Nusa Tenggara Timur 2018. Kupang: BPS Provinsi NTT.

Badan Pusat Statistik Provinsi NTT. (2019b). Sampling Error Estimasi Hasil Survei Pertanian Antar Sensus (Sutas) 2018 Provinsi Nusa Tenggara Timur (Bidang Produksi Statistik (ed.) Issue 09). Kupang: BPS Provinsi NTT.

Badan Pusat Statistik Provinsi NTT. (2020). Provinsi Nusa Tenggara Timur dalam Angka 2020 (Badan Integrasi Pengolahan dan Diseminasi Statistik (ed.)). BPS Provinsi NTT. Retrieved from https://ntb.bps.go.id/.

Basuki, A. T. (2012). Pengembangan kawasan agropolitan. Jurnal Ekonomi \& Studi Pembangunan, 13(1), 53-71. https://jour nal.umy.ac.id/index.php/esp/article/view/ 1291.

Dinas Kependudukan dan Pencatatan Sipil Kota Bontang. (2013). Jumlah dan proporsi penduduk menurut umur dan jenis kelamin. Retrieved from http:// disdukcapil.bontangkota.go.id/index.php/ data-agregat/108-profil/profil-2010/148jumlah-dan-proporsi-penduduk-menurutumur-dan-jenis-kelamin.
Hamdi, A. S., \& Bahruddin, E. (2015). Metode Kuantitatif Aplikasi dalam Pendidikan. Yogyakarta: Deepublish.

Heryanah, H. (2015). Ageing population dan bonus demografi kedua di Indonesia Populasi, 23(2), 1-16. https://doi.org/ 10.22146/JP.15692.

Ichwandi, I. (2014). Membumikan kebijakan ketahanan pangan. Risalah Kebijakan Pertanian dan Lingkungan Rumusan Kajian Strategis Bidang Pertanian dan Lingkungan, 1(2), 97-104. https://jurnal. ipb.ac.id/index.php/jkebijakan/article/vie w/10300.

Kementerian Pertanian RI. (2020). Rencana Strategis Kementerian Pertanian 20202024. Biro Perencanaan, Sekretariat Jenderal, Kementerian Pertanian RI. Retrieved from http://perencanaan.setjen .pertanian.go.id/public/upload/file/20200 626095809Renstra-2020-2024-web.pdf.

Mardiyaningsih, D. I., \& Dharmawan, A. H. (2010). Dinamika sistem penghidupan masyarakat tani tradisional dan modern di Jawa Barat. Sodality: Jurnal Sosiologi Pedesaan, 4(1), 115-145. https://doi.org/ 10.22500/SODALITY.V4I1.5850.

Moniaga, V. R. B. (2011). Analisis daya dukung lahan pertanian. Agrisosio ekonomi, 7(2), 61-68. https://doi.org/ 10.35791/AGRSOSEK.7.2.2011.92.

Nirzalin, \& Maliati, N. (2017). Agricultural productivity and farmers welfare involution (case study in Meunasah Pinto Aceh Utara). Sodality: Jurnal Sosiologi Pedesaan, 5(2). https://doi.org/10.22500/ SODALITY.V5I2.17970.

Undang-undang No. 18 Tahun 2012 tentang Pangan, Pub. L. No. 5360. (2012). Retrieved from https://luk.staff.ugm.ac. id/atur/UU18-2012Pangan.pdf.

Pratama, A. R., Sudrajat, S., \& Harini, R. (2019). Analisis ketersediaan dan kebutuhan beras di Indonesia tahun 2018. Media Komunikasi Geografi, 20(2), 101-114. https:// doi.org/10.23887 /MKG.V20I2.19256. 
Sumunar, A. A. K., Budiman, S. : Proyeksi Ketahanan Pangan Provinsi ...

Rukajat, A. (2018). Pendekatan Penelitian Kuantitatif: Quantitative Research Approach. Yogyakarta: Deepublish.

Teda, F. E., Benu, F. L., \& Wiendiyati, W. (2020). Upaya memperbaiki ekonomi beras di Provinsi Nusa Tenggara Timur analisis data sekunder tahun 2003-2017. Buletin Ilmiah IMPAS, 21(2), 91-101. https://doi.org/10.35508/IMPAS.V21I02. 2623.

Vecchi, G. A., \& Wittenberg, A. T. (2010). El Niño and our future climate: where do we stand? Wiley Interdisciplinary
Reviews: Climate Change, 1(2), 260270. https://doi.org/10.1002/WCC.33.

Widodo, H., Pratiwi, R. N., \& Saleh, C. (2013). Perencanaan pembangunan distribusi dan akses pangan masyarakat (studi pada Kantor Ketahanan Pangan Kabupaten Banyuwangi). Sosial Dan Humaniora, 16(4), 223-232. https://wacaba.ub.ac.id/ index.php/wacana/article/view/303.

Yusuf, A. M. (2017). Metode Penelitian Kuantitatif, Kualitatif, \& Penelitian Gabungan. Yogyakarta: Deepublish. 